\title{
BRAF mutations in papillary thyroid carcinoma and emerging targeted therapies (Review)
}

\author{
GIULIA COSTANZA LEONARDI ${ }^{1}$, SAVERIO CANDIDO ${ }^{1}$, MAURIZIO CARBONE ${ }^{2}$, FABIO RAITI ${ }^{1}$, \\ VALERIA COLAIANNI $^{2}$, SEBASTIANO GAROZZO ${ }^{2}$, DIANA CINÀ $^{2}$, JAMES A. McCUBREY $^{3}$ and MASSIMO LIBRA ${ }^{1}$ \\ ${ }^{1}$ Department of Biomedical Sciences, Section of Pathology and Oncology, Laboratory of Translational Oncology \\ and Functional Genomics, University of Catania; ${ }^{2}$ Clinical Pathology Laboratory, Garibaldi Hospital, Catania, Italy; \\ ${ }^{3}$ Department of Microbiology and Immunology, Brody School of Medicine, East Carolina University, Greenville, NC, USA
}

Received April 30, 2012; Accepted May 21, 2012

DOI: $10.3892 / \mathrm{mmr} .2012 .1016$

\begin{abstract}
Papillary thyroid carcinoma (PTC) is the most common histotype among the thyroid cancer types. Although PTC is a curable malignancy, many patients relapse after treatment. Thus, there is a need to identify novel factors involved in the pathogenesis of PTC that may be used as targets for new therapies. The MAPK pathway has been implicated in the pathogenesis of PTC. Therefore, in this review, we summarize the role of the BRAF V600E mutation in the development and progression of thyroid cancer. The cinical implication of this molecular abnormality is also discussed. It is evident that the detection of the BRAF V600E mutation is crucial in order to identify novel avenues for thyroid cancer treatment.
\end{abstract}

\section{Contents}

1. Introduction

2. BRAF V600E mutation

3. Effects of BRAF mutation on PTC

4. Correlation of V600E mutation with PTC pathological features

5. Detection of V600E mutation in PTC recurrence

6. Conclusion

\section{Introduction}

Papillary thyroid carcinoma (PTC) is the most common histotype among thyroid tissue malignancies, accounting for approximately $80 \%$ of all thyroid cancers (1). The growing

Correspondence to: Dr Massimo Libra, Department of Biomedical Sciences, Section of Pathology and Oncology, Laboratory of Translational Oncology and Functional Genomics, University of Catania, Via Androne 83, I-95124 Catania, Italy

E-mail:mlibra@unict.it

Key words: thyroid cancer, BRAF mutations, V600E, targeted therapies incidence of thyroid cancer is almost entirely ascribed to PTC $(2,3)$. The epidemiology of PTC has evoked much interest. Dietary iodine deficiency appears to influence the incidence of the disease, and in some cases, the morphology of the papillary carcinomas (4). However, as regards the etiology of PTC, a number of studies have revealed an association between its incidence and development with radiation exposure (5-7).

Differentiated thyroid cancer, including PTC, tends to be biologically indolent, highly curable and has an excellent prognosis. A number of clinicopathological features are considered as high-risk factors in PTC $(8,9)$. These include: old patient age at the time of diagnosis, male gender, large tumor size, extrathyroidal invasion, lymph node metastasis, distant metastasis, and advanced disease stages (8,10-12). All of these clinical characteristics are associated with poor prognosis as they reflect an aggressive tumor behavior with an increased rate of progression and recurrence. Finally, the histological criteria are important to stratify the risk of disease aggressiveness for the patients (13-16). All the cited elements are useful for a more appropriate therapeutic approach of PTC and subsequent follow-up. It has been shown that the accuracy of this clinicopathological criteria-based method can be unreliable for patients with conventionally low clinicopathological stages $(11,17)$. Although PTC is highly curable with standard surgical treatment and radioiodine ablation therapy, a significant recurrence rate (approximately 20\% at 10 years and 30\% at 30 years of follow-up) is observed after treatment and many patients still succumb to the disease. Additionally, there are no therapeutic options for those patients who develop radioiodine resistance and are not eligible for surgery. Risk stratification is the chief consideration in determining the appropriate management of PTC-affected patients. Therefore, it is important to improve the reliability of this system in order to reduce the recurrence rate as well as the mortality of PTC.

Thyroid cancer carries several highly prevalent genetic alterations, some of which are observed only in this type of cancer. These oncogenic alterations include: Ras mutations $(19,20)$, RET/PTC rearrangements $(21,22)$ and PAX8-peroxisome proliferator-activated receptor $\gamma(\operatorname{PPAR} \gamma)$ fusion oncogene $(23,24)$. In PTC tumors, RET/PTC rearrangement and point mutations of the BRAF and RAS genes are found in over $70 \%$ of papillary carcinomas and they rarely overlap in the same tumor (25). 
The BRAF gene is highly mutated in tumor cells and over 40 different mutations have been identified. The BRAF V600E mutation is the most common and accounts for more than $90 \%$ of all the mutations found in the BRAF gene (26). Moreover, this mutation has been found to occur frequently in thyroid cancer (27-32). Intriguingly, the BRAF mutation in thyroid cancer occurs exclusively in PTC and PTC-derived anaplastic thyroid carcinoma (ATC) and it does not occur in follicular thyroid carcinoma (FTC) or other types of thyroid tumors (33). As highlighted in the study by Xing, the prevalence and specificity of the BRAF mutation in PTC cells may be associated with a pathogenic role of this mutation in this tumor. The fine-needle aspiration is a pre-operative approach useful for diagnosis that should be completed by screening for the BRAF V600E mutation. Targeted therapy may prove to be advantageous for PTC patients harboring this molecular aberration (33).

In the present review, the role of BRAF mutations in the development and progression of thyroid cancer and their implications for novel therapeutic strategies are summarized.

\section{BRAF V600E mutations}

The 'MAPK pathway' [the RET/PTC $\rightarrow$ Ras $\rightarrow$ Raf $\rightarrow$ mitogen extracellular kinase $(\mathrm{MEK}) \rightarrow \mathrm{MAPK} / \mathrm{ERK}$ pathway] is a fundamental intracellular signaling pathway that plays a central role in cellular functions, such as proliferation, differentiation, apoptosis and survival (34-38). The aberrant activation of the MAPK pathway, through the activation of genetic alterations of its elements, has been observed in many human cancers (39-43) (Fig. 1). The B-type Raf kinase (BRAF) mutation was discovered to be a leading cause of aberrant activation of the MAPK pathway in human cancers (44). There are three Raf kinases, A-Raf, BRAF (BRAF) and C-Raf. Among the three, BRAF is the most potent activator of the MAPK pathway in many cells (37).

The wild-type BRAF gene is localized on chromosome 7 and is composed of 119 base pairs (bp). Most of BRAF mutations are clustered within exons 11 and 15 (44). The T1799A mutation results in a V600E amino acid substitution in the protein product and subsequent constitutive activation of the BRAF kinase and ERK phosphorylation (44-46). Accordingly, dysregulated signaling through the activation of Ras/Raf/MEK/ ERK and PI3K/PTEN/Akt/mTOR pathways is often the result of genetic alterations in critical components in these pathways, as well as mutations in upstream growth factor receptors (47). Another BRAF mutation detected in thyroid tumors is the K601E mutation which has been observed in two benign thyroid adenomas $(31,48)$ and three follicular-variant PTCs $(49)$. The mutations in exon 11 of the BRAF gene found in other human cancers have not been found in thyroid cancer (27-30,50-52). The in vivo fusion of the BRAF gene with the AKAP9 gene through a paracentric inversion of the long arm of chromosome 7 may cause BRAF activation. This aberration has been observed in PTC patients with a history of radiation exposure $(53,54)$.

\section{Effects of BRAF mutation on PTC}

Strong molecular bases have now been revealed for BRAF mutation-promoted invasiveness and the progression of PTC. It has been shown that transgenic mice develop PTC after injection of the BRAF V600E protein in the thyroid gland (55). Previous studies have shown that BRAF V600E promotes the invasion of thyroid cells in a rat cell line model (56). Ouyang et al demonstrated that BRAF inhibitors can inhibit the growth and proliferation of cells harboring the BRAF V600E mutation (57). As previously shown, siRNA transfection of PTC cells harboring the BRAF mutation resulted in the persistent suppression of BRAF, sustained the inhibition of cell proliferation, prevented transformation even after long-term culture and inhibited xenograft tumor growth in nude mice $(58,59)$.

As already mentioned above, the activating genetic alterations in the MAPK pathway, including RET/PTC rearrangement, Ras mutation and BRAF mutation, are mutually exclusive in PTC, suggesting that each of these genetic alterations in PTC may be sufficient on their own to drive PTC tumorigenesis (25). Conversely, as shown in a previous study, the expression of RET/PTC did not cause genetic instability that was observed in rat thyroid cells after induction of BRAF V600E (60). Mesa et al showed that in rat thyroid cell lines, an increased Matrigel cell invasion was observed with the induced expression of BRAF V600E, but not with RET/PTC rearrangement (56).

Microarray gene expression analyses have displayed different gene expression patterns in cells harboring the BRAF V600E mutation or RET/PTC rearrangement, suggesting a difference in the genes affected by the two genetic alterations and indicating that the BRAF mutant is possibly a stronger activator of the MAPK pathway than $\operatorname{RET} / \mathrm{PTC}(56,61,62)$.

It has been also demonstrated in PTC that the BRAF mutation is linked with the aberrant methylation of different tumor suppressor genes, including the genes, tissue inhibitor of matrix metalloproteinase-3 (TIMP3), death-associated protein kinase (DAPK), SLC5A8 and retinoic acid receptor $\beta 2$ (RARß2) (63-66). It is known that TIMP3 suppresses tumor growth, angiogenesis, invasion and metastasis by preventing the interstitial matrix destruction promoted by matrix metalloproteinase (MMP)-3 (67) and by blocking the binding of vascular endothelial growth factor (VEGF) to the VEGF receptor (68). The BRAF mutation has been reported to be associated with alterations in the expression of various micro-RNAs that appear to have tumor-suppressor potential in PTC (69-71). The BRAF V600E mutation in thyroid cell lines is also involved in the upregulation of tumor-promoting molecules, such as MMPs $(56,61,72)$. In the study by Palona et $\mathrm{al}$, the authors also showed that BRAF V600E promoted the activation of the nuclear transcription factor $\kappa \mathrm{B}(\mathrm{NF}-\kappa \mathrm{B})$ coupled signaling, which in turn promoted the Matrigel invasion of thyroid cancer cells (72). Intriguingly, BRAF V600E promoted the activation of NF- $\mathrm{B}$ through signaling directly from BRAF, independently of the downstream MEK/ MAPK/ERK signaling pathway (72-74). Moreover, it has been demonstrated that the overexpression of VEGF is associated with BRAF mutation in PTC (75). Recently, Grabellus et al showed that glucose transporter 1 (GLUT1) is a target of the constitutive activation of the RAF/MEK/ERK pathway, hypothesizing that the BRAF mutation in PTC may contribute to the initiation of the glycolytic phenotype and may confer growth advantages in cancer cells (76).

Taken together, all these elements suggest the critical role played by the BRAF mutation in promoting extrathyroidal invasion and metastasis (which involves vigorous angiogenesis 


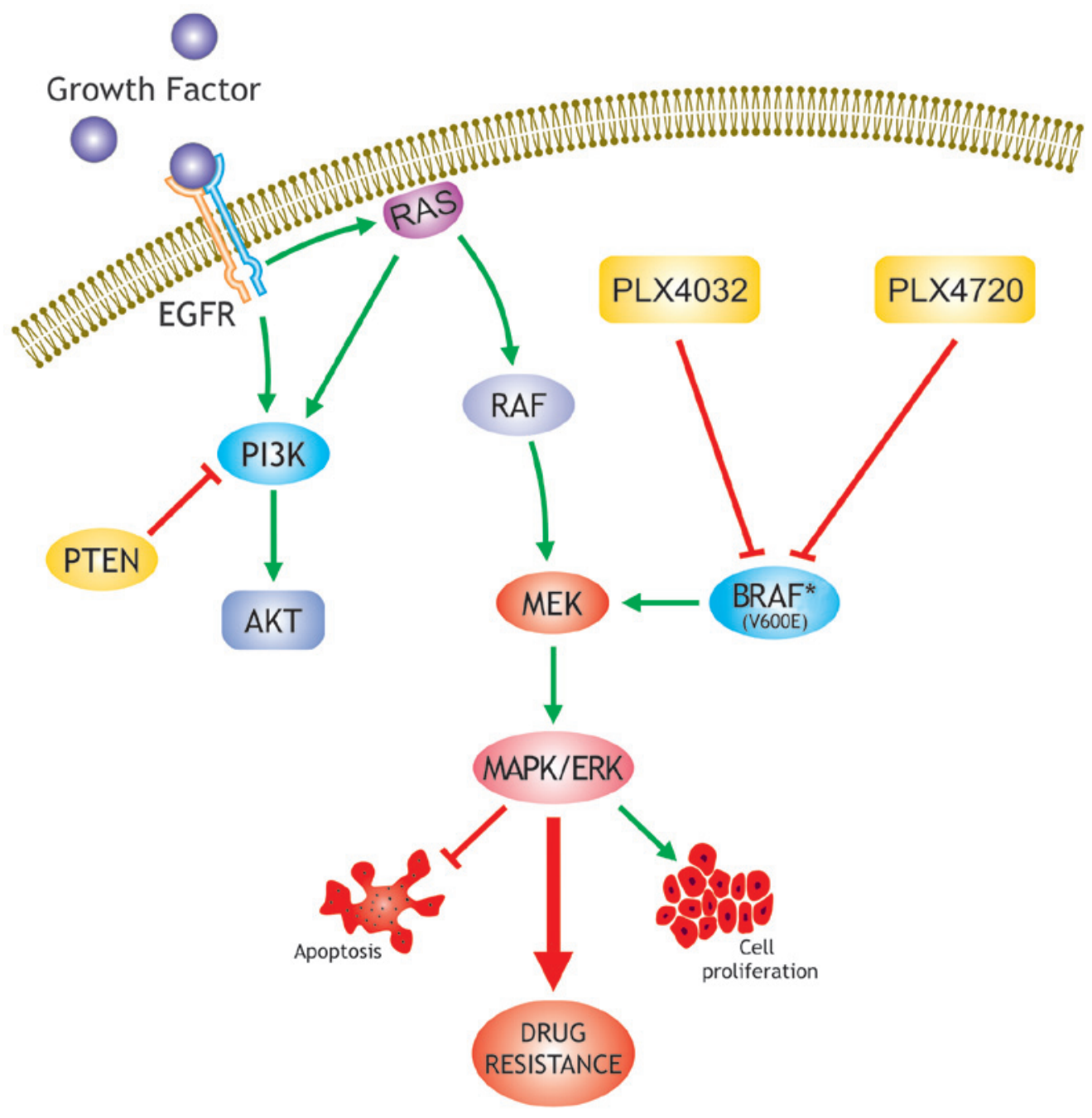

Figure 1. Scheme of the MAPK molecular pathway describing the role of the BRAF V600E mutation in tumor growth and how the BRAF inhibitors, PLX4032 and PLX4720, block cellular proliferation by inducing apoptosis.

and tissue invasion) and the mutation-mediated progression and aggressiveness of PTC.

The efficacy of radioiodine ablation therapy for the treatment of thyroid cancer depends on the ability of the cancer cells to absorb and accumulate radioiodine, which in turn relies on the integrity of the iodide-metabolizing system of the thyroid cell (77). The expression of the thyroid iodidemetabolizing genes is often impaired or lost in thyroid cancer $(78,79)$. Intriguingly, the BRAF mutation has ben found to be associated with the decreased expression of thyroperoxidase $(62,80-82)$, sodium/iodide symporter $(80,83)$, thyroglobulin (80) and pendrin (81) in primary or recurrent PTC tumors. The conditional expression of BRAF V600E in rat thyroid cell lines has led to the silencing of all these thyroidspecific iodide-metabolizing genes $(60,83,84)$. The MAPK inhibitors or BRAF siRNA could re-establish the expression of these genes $(83,84)$. Several studies have demonstrated that the thyroid-stimulating hormone (TSH) receptor gene is silenced in a promoter methylation-dependent manner in rat thyroid cell lines $(85,86)$, as well as human thyroid cancer cells $(87,88)$. Xing suggested that the silencing of thyroid-specific genes associated with the BRAF mutation supports the notion that the BRAF mutation promotes the progression and aggressiveness of PTC (89).

\section{Correlation of V600E mutation with PTC pathological features}

A positive correlation between the BRAF V600E mutation with the clinicopathological characteristics of PTC, including extrathyroidal invasion, lymph node metastasis and advanced stages has been identified in a number of studies (83,90,93-97, $99,100,102,103,105,107,109-111,113,115,117)$. Accordingly, the metanalysis performed by Xing in 2007 confirmed such an association, displaying overall odds ratios of 2.50 [95\% confidence interval (CI) 2.11-2.97], 1.83 (95\% CI 1.58-2.13) and 2.14 (95\% CI 1.79-2.56) (89). BRAF mutations have also been observed in 77, 60 and $12 \%$ of tall cell PTCs, conventional PTCs and follicular variant PTCs, respectively. These data support the notion that the V600E mutation detected in BRAF is associated with the aggressive variants of PTC $(33,110)$. Furthermore, it has previously been suggested that the BRAF mutation renders PTC prone to progress into the more aggressive ATC (105,118-120). 
As considered above, the association between BRAF mutation and the conventional high-risk clinicopathological factors in PTCs is supported by several studies; however, other studies have failed to reveal such an association $(54,75,80,90$, 92,98,101,104,106, 108,112,114,115,121).

Conflicting data have also been generated regarding the correlation between BRAF mutations, old age, male gender, thyroid cancer progression and aggressiveness $(32,91,92,95,96$, $100,105,107,109,111,114,115,117,122)$. This controversy may be supported by different hypotheses that have been properly considered by Xing in 2007, such as different diagnostic criteria and the small number of cases analyzed in some published studies (89).

\section{Detection of V600E mutation in PTC recurrence}

The association between BRAF mutation and PTC recurrence has been explored in several studies. Kim et al demonstrated a close association between the BRAF mutation and tumor recurrence in 203 patients with conventional PTC (99). A strong association between the BRAF mutation and the recurrence of PTC has also been confirmed by Riesco-Eizaguirre et al (83). In a large study by Xing et al, an odds ratio of $4.0(95 \% \mathrm{CI}$ 1.1-14.1; $\mathrm{P}=0.03$ ) for cancer recurrence with the BRAF mutation was obtained by multivariate analysis with adjustment for all the confounding clinicopathological factors, including tumor subtypes and a history of radioiodine treatment. Interestingly, such an association was even established in a subgroup of patients with low-grade initial clinicopathological stages I and II, usually linked with a low risk of recurrence (110). Despite this evidence however, in 2011, Cañadas Garre et al found no association between BRAF mutation and the recurrence of PTC (114).

The core of the current medical treatment of PTC following thyroidectomy is radioiodine ablation therapy. The medical treatment of recurrent PTC is also largely confined to radioiodine therapy $(8,9,123)$. Although various clinicopathological factors are known to predict an increased risk of recurrence of thyroid cancer, no factors have been associated with the loss of radioiodine avidity, mainly responsible for treatment failure. On this regard, Xing et al showed that patients harboring BRAF mutations in the primary PTC tumor developed a recurrence with an aggressive course of disease, to be treated with surgery and external radiation therapy. However, PTC patients with recurrent tumors that did not display any BRAF mutation in the primary tumor may be treated with radioiodine therapy, suggesting a better clinical behavior (110). The association between BRAF mutation in primary or recurrent PTC and the loss of radioiodine avidity in the recurrent tumor, was observed in two studies; however, such an association did not reach statistical significance $(81,83)$.

\section{Conclusion}

From both the clinicopathological and molecular biological evaluations, it is evident that BRAF mutations are fundamentally associated with the increased progression and aggressiveness of PTC. Several studies have shown that BRAF mutations may be considered as powerful markers for PTC recurrence risk $(83,95,99,110)$. BRAF mutations can be easily detected in tumor DNA from thyroid fine-needle aspiration biopsy (FNAB). Surgical and medical treatments can be better applied if the BRAF mutation status is determined from thyroid FNAB $(33,94,124-128)$.

It is evident that the MAPK pathway plays a major role in tumorigenesis and the progression of PTC and may be consequently considered as a potentially effective therapeutic target for PTC.

In recent years, the inhibition of MAPK pathway has been investigated in human cancers, generating interesting results (reviewed in refs. 34-38,42). The silencing of the MAPK pathway by Raf kinase inhibitors, such as AAL-881 and LBT-613, has been shown to result in the inhibition of BRAFmutated thyroid cancer cell proliferation (57-59). Moreover, Liu et al showed that through a stable siRNA knockdown of BRAF, thyroid cells were able to differentiate as reflected by the restoration of the expression of some thyroid-specific genes (84).

The results from an advanced human thyroid cancer preclinical study suggest that PLX4720, an orally available BRAF V600E inhibitor, may be used in clinical trials for the treatment of patients with BRAF V600E-positive thyroid cancers, refractory to conventional therapy (129-131). MEK inhibitors are another class of highly promising therapeutic agents for thyroid cancer. Liu et al showed that CI-1040, a potent small molecule MEK-selective inhibitor, which inhibits both MEK-1 and MEK-2, inhibited the growth and proliferation of thyroid cancer cells harboring mutant BRAF but not wild-type BRAF. The study also demonstrated that the CI-1040 compound preferentially induced the differentiation of some thyroid cancer cells that harbored the BRAF mutation (132). Namba et al showed that another MEK-inhibitor, U0126, inhibited cell proliferation in thyroid cancer cells harboring the BRAF mutation (30) and these findings were confirmed in the study by Henderson et al (133). This chemically synthesized compound, however, cannot be developed clinically due to its limited solubility and bioavailability (134). More potent and pharmaceutically superior second-generation MEK inhibitors, such as the PD-0325901 compound and the ARRY-142886 (AZD6244) compound (134,135), are currently under development and are being used in clinical trials. Several clinical trials with BRAF inhibitors and MEK inhibitors are currently under evaluation, presenting a new perspective in PTC treatment. Therefore, it is evident that the detection of the BRAF V600E mutation is crucial in order to identify novel avenues for thyroid cancer treatment.

\section{References}

1. Jemal A, Siegel R, Ward E, Hao Y, Xu J and Thun MJ: Cancer statistics, 2009. CA Cancer J Clin 59: 225-249, 2009.

2. Davies L and Welch HG: Increasing incidence of thyroid cancer in the United States, 1973-2002. JAMA 295: 2164-2167, 2006.

3. Leenhardt L, Grosclaude P and Cherie-Challine L: Increased incidence of thyroid carcinoma in France: a true epidemic or thyroid nodule management effects? Report from the French Thyroid Cancer Committee. Thyroid 14: 1056-1060, 2004.

4. Williams ED, Abrosimov A, Bogdanova T, Demidchik EP, Ito M, LiVolsi V, Lushnikov E, Rosai J, Tronko MD, Tsyb AF, Vowler SL and Thomas GA: Morphologic characteristics of Chernobyl-related childhood papillary thyroid carcinomas are independent of radiation exposure but vary with iodine intake. Thyroid 18: 847-852, 2008.

5. Hunt JL: Radiation induced thyroid diseases. Pathol Case Rev 14: 224-230, 2009 
6. Nakachi K, Hayashi T, Hamatani K, Eguchi H and Kusunoki Y: Sixty years of follow-up of Hiroshima and Nagasaki survivors: cancer progress in molecular epidemiology studies. Mutat Res 659: 109-117, 2008.

7. Williams D: Radiation carcinogenesis: lessons from Chernobyl. Oncogene 27: 9-18, 2009 .

8. Sherman SI, Angelos P, Ball DW, Beenken SW, Byrd D, Clark OH, Daniels GH, Dilawari RA, Ehya H, Farrar WB, et al: Thyroid carcinoma. J Natl Compr Canc Netw 3: 404-457, 2005.

9. Cooper DS, Doherty GM, Haugen BR, Kloos RT, Lee SL, Mandel SJ, Mazzaferri EL, McIver B, Sherman SI and Tuttle RM: Management guidelines for patients with thyroid nodules and differentiated thyroid cancer. Thyroid 16: 109-142, 2006.

10. Mazzaferri EL: Long-term outcome of patients with differentiated thyroid carcinoma: effect of therapy. Endocr Pract 6: 469-476, 2000

11. Mazzaferri EL and Kloos RT: Clinical review 128: current approaches to primary therapy for papillary and follicular thyroid cancer. J Clin Endocrinol Metab 86: 1447-1463, 2001.

12. Tanaka K, Sonoo H, Hirono M, Ohkubo S, Nomura T, Ikeda M, Nakajima K and Kurebayashi J: Retrospective analysis of predictive factors for recurrence after curatively resected papillary thyroid carcinoma. Surg Today 35: 714-719, 2005.

13. Chan JK: Papillary carcinoma of thyroid: classical and variants. Histol Histopathol 5: 241-257, 1990.

14. Lang BH, Lo CY, Chan WF, Lam AK and Wan KY: Classical and follicular variant of papillary thyroid carcinoma: a comparative study on clinicopathologic features and long-term outcome. World J Surg 30: 752-758, 2006.

15. Keelawat $\mathrm{S}$ and Poumsuk U: Association between different variants of papillary thyroid carcinoma and risk-group according to AMES (age, metastasis, extent and size) classification system. J Med Assoc Thai 89: 484-489, 2006.

16. Michels JJ, Jacques M, Henry-Amar M and Bardet S: Prevalence and prognostic significance of tall cell variant of papillary thyroid carcinoma. Hum Pathol 38: 212-219, 2007.

17. Mazzaferri EL: Managing small thyroid cancers. JAMA 295 2179-2182, 2006.

18. Mazzaferri EL and Jhiang SM: Long-term impact of initial surgical and medical therapy on papillary and follicular thyroid cancer. Am J Med 97: 418-428, 1994.

19. Fagin JA: Minireview: branded from the start-distinct oncogenic initiating events may determine tumor fate in the thyroid. Mol Endocrinol 16: 903-911, 2002.

20. Bongarzone I and Pierotti MA: The molecular basis of thyroid epithelial tumorigenesis. Tumori 89: 514-516, 2003.

21. Nikiforov YE: RET/PTC rearrangement in thyroid tumors. Endocrine Pathology 13: 3-16, 2002.

22. Tallini G: Molecular pathobiology of thyroid neoplasms. Endocr Pathol 13: 271-288, 2002

23. Kroll TG, Sarraf P, Pecciarini L, Chen CJ, Mueller E, Spiegelman BM and Fletcher JA: PAX8- PPARgamma1 fusion oncogene in human thyroid carcinoma. Science 289: 1357-1360, 2000.

24. McIver B, Grebe SK and Eberhardt NL: The PAX8/ PPARgamma fusion oncogene as a potential therapeutic target in follicular thyroid carcinoma. Curr Drug Targets Immune Endocr Metabol Disord 4: 221-234, 2004.

25. Nikiforova MN and Nikiforov YE: Molecular genetics of thyroid cancer: implications for diagnosis, treatment and prognosis. Expert Rev Mol Diagn 8: 83-95, 2008.

26. Garnett MJ and Marais R: Guilty as charged: B-RAF is a human oncogene. Cancer Cell 6: 313-319, 2004

27. Cohen Y, Xing M, Mambo E, Guo Z, Wu G, Trink B, Beller U, Westra WH, Ladenson PW and Sidransky D: BRAF mutation in papillary thyroid carcinoma. J Natl Cancer Inst 95: 625-627, 2003.

28. Fukushima T, Suzuki S, Mashiko M, Ohtake T, Endo Y, Takebayashi Y, Sekikawa K, Hagiwara K and Takenoshita S: BRAF mutations in papillary carcinomas of the thyroid. Oncogene 22: 6455-6457, 2003.

29. Kimura ET, Nikiforova MN, Zhu Z, Knauf JA, Nikiforov YE and Fagin JA: High prevalence of BRAF mutations in thyroid cancer: genetic evidence for constitutive activation of the RET/ PTC-RAS-BRAF signaling pathway in papillary thyroid carcinoma. Cancer Res 63: 1454-1457, 2003

30. Namba H, Nakashima M, Hayashi T, Hayashida N, Maeda S, Rogounovitch TI, Ohtsuru A, Saenko VA, Kanematsu T and Yamashita S: Clinical implication of hot spot BRAF mutation, V599E, in papillary thyroid cancers. J Clin Endocrinol Metab 88: 4393-4397, 2003.
31. Soares P, Trovisco V, Rocha AS, Lima J, Castro P, Preto A, Maximo V, Botelho T, Seruca R and Sobrinho-Simões M: BRAF mutations and RET/PTC rearrangements are alternative events in the etiopathogenesis of PTC. Oncogene 22: 4578-4580, 2003.

32. Xu X, Quiros RM, Gattuso P, Ain KB and Prinz RA: High prevalence of BRAF gene mutation in papillary thyroid carcinomas and thyroid tumor cell lines. Cancer Res 63: 4561-4567, 2003.

33. Xing M: BRAF mutation in thyroid cancer. Endocr Relat Cancer 12: 245-262, 2005.

34. Pritchard $C$ and McMahon M: Raf revealed in life-or-death decisions. Nat Genet 16: 214-215, 1997.

35. McCubrey JA, Steelman LS, Chappell WH, Abrams SL, Wong EW, Chang F, Lehmann B, Terrian DM, Milella M, Tafuri A, et al: Roles of the Raf/MEK/ERK pathway in cell growth, malignant transformation and drug resistance. Biochim Biophys Acta 1773: 1263-1284, 2007.

36. Steelman LS, Abrams SL, Shelton JG, Chappell WH, Bäsecke J, Stivala F, Donia M, Nicoletti F, Libra M, Martelli AM and McCubrey JA: Dominant roles of the Raf/MEK/ERK pathway in cell cycle progression, prevention of apoptosis and sensitivity to chemotherapeutic drugs. Cell Cycle 9: 1629-1638, 2010.

37. Steelman LS, Chappell WH, Abrams SL, Kempf RC, Long J, Laidler P, Mijatovic S, Maksimovic-Ivanic D, Stivala F, Mazzarino MC, et al: Roles of the Raf/MEK/ERK and PI3K/ PTEN/Akt/mTOR pathways in controlling growth and sensitivity to therapy-implications for cancer and aging. Aging (Albany NY) 3: 192-222, 2011

38. Chappell WH, Steelman LS, Long JM, Kempf RC, Abrams SL, Franklin RA, Bäsecke J, Stivala F, Donia M, Fagone P, et al: Ras/Raf/MEK/ERK and PI3K/PTEN/Akt/mTOR inhibitors: rationale and importance to inhibiting these pathways in human health. Oncotarget 2: 135-164, 2011.

39. Hoshino R, Chatani Y, Yamori T, Tsuruo T, Oka H, Yoshida O, Shimada Y, Ari-i S, Wada H, Fujimoto J and Kohno M: Constitutive activation of the 41-/43-kDa mitogen-activated protein kinase signaling pathway in human tumors. Oncogene 18: 813-822, 1999.

40. Ciampi R and Nikiforov YE: RET/PTC rearrangements and BRAF mutations in thyroid tumorigenesis. Endocrinology 148: 936-941, 2007.

41. Santoro M, Melillo RM and Fusco A: RET/PTC activation in papillary thyroid carcinoma: European Journal of Endocrinology Prize Lecture. Eur J Endocrinol 155: 645-653, 2006.

42. Russo AE, Torrisi E, Bevelacqua Y, Perrotta R, Libra M, McCubrey JA, Spandidos DA, Stivala F and Malaponte G: Melanoma: molecular pathogenesis and emerging target therapies (Review). Int J Oncol 34: 1481-1489, 2009.

43. Steelman LS, Navolanic PM, Franklin RA, Bonati A, Libra M, Stivala F, Martelli AM and McCubrey JA: Combining chemo-, hormonal and targeted therapies to treat breast cancer (Review). Mol Med Report 1: 139-160, 2008.

44. Davies H, Bignell GR, Cox C, et al: Mutations of the BRAF gene in human cancer. Nature 417: 949-954, 2002.

45. Dhillon AS and Kolch W: Oncogenic B-Raf mutations: crystal clear at last. Cancer Cell 5: 303-304, 2004.

46. Hubbard SR: Oncogenic mutations in B-Raf: some losses yield gains. Cell 116: 764-766, 2004.

47. McCubrey JA, Steelman LS, Kempf CR, Chappell WH, Abrams SL, Stivala F, Malaponte G, Nicoletti F, Libra M, Bäsecke $\mathrm{J}$, et al: Therapeutic resistance resulting from mutations in Raf/MEK/ERK and PI3K/PTEN/Akt/mTOR signaling pathways. J Cell Physiol 226: 2762-2781, 2011.

48. Lima J, Trovisco V, Soares P, Máximo V, Magalhães J, Salvatore G, Santoro M, Bogdanova T, Tronko M, Abrosimov A, et al: BRAF mutations are not a major event in post-Chernobyl childhood thyroid carcinomas. J Clin Endocrinol Metab 89: 4267-4271, 2004

49. Trovisco V, Vieira de Castro I, Soares P, Maximo V, Silva P, Magalhaes J, Abrosimov A, Guiu XM and Sobrinho-Simões M: BRAF mutations are associated with some histological types of papillary thyroid carcinoma. J Pathol 202: 247-251, 2004.

50. Frattini M, Ferrario C, Bressan P, Balestra D, De Cecco L, Mondellini P, Bongarzone I, Collini P, Gariboldi M, Pilotti S, Pierotti MA and Greco A: Alternative mutations of BRAF, RET and NTRK1 are associated with similar but distinct gene expression patterns in papillary thyroid cancer. Oncogene 23: 7436-7740, 2004

51. Perren A, Schmid S, Locher T, Saremaslani P, Bonvin C, Heitz PU and Komminoth P: BRAF and endocrine tumors: mutations are frequent in papillary thyroid carcinomas, rare in endocrine tumors of the gastrointestinal tract and not detected in other endocrine tumors. Endocr Relat Cancer 11: 855-860, 2004. 
52. Puxeddu E, Moretti S, Elisei R, Romei C, Pascucci R, Martinelli M, Marino C, Avenia N, Rossi ED, Fadda G, et al: BRAF(V599E) mutation is the leading genetic event in adult sporadic papillary thyroid carcinomas. J Clin Endocrinol Metab 89: 2414-2420, 2004.

53. Ciampi R, Knauf JA, Kerler R, Gandhi M, Zhu Z, Nikiforova MN, Rabes HM, Fagin JA and Nikiforov YE: Oncogenic AKAP9-BRAF fusion is a novel mechanism of MAPK pathway activation in thyroid cancer. J Clin Invest 115: 94-101, 2005.

54. Fusco A, Viglietto G and Santoro M: A new mechanism of BRAF activation in human thyroid papillary carcinomas. J Clin Invest 115: 20-23, 2005 .

55. Knauf JA, Ma X, Smith EP, Zhang L, Mitsutake N, Liao XH, Refetoff S, Nikiforov YE and Fagin JA: Targeted expression of BRAFV600E in thyroid cells of transgenic mice results in papillary thyroid cancers that undergo dedifferentiation. Cancer Res 65: 4238-4245, 2005

56. Mesa Jr C, Mirza M, Mitsutake N, Sartor M, Medvedovic M, Tomlinson C, Knauf JA, Weber GF and Fagin JA: Conditional activation of RET/PTC3 and BRAFV600E in thyroid cells is associated with gene expression profiles that predict a preferential role of BRAF in extracellular matrix remodeling. Cancer Res 66: 6521-6529, 2006.

57. Ouyang B, Knauf JA, Smith EP, Zhang L, Ramsey T, Yusuff N, Batt D and Fagin JA: Inhibitors of Raf kinase activity block growth of thyroid cancer cells with RET/PTC or BRAF mutations in vitro and in vivo. Clin Cancer Res 12: 1785-1793, 2006.

58. Liu D, Liu Z, Condouris S and Xing M: BRAF V600E maintains proliferation, transformation, and tumorigenicity of BRAFmutant papillary thyroid cancer cells. J Clin Endocrinol Metab 92: 2264- 2271, 2007.

59. Salvatore G, Falco V, Salerno P, Nappi T, Pepe S, Troncone G, Carlomagno F, Melillo R, Wilhelm SM and Santoro M: BRAF is a therapeutic target in aggressive thyroid carcinoma. Clin Cancer Res 12: 1623-1629, 2006

60. Mitsutake N, Knauf JA, Mitsutake S, Mesa Jr C, Zhang L and Fagin JA: Conditional BRAFV600E expression induces DNA synthesis, apoptosis, dedifferentiation, and chromosomal instability in thyroid PCCL3 cells. Cancer Res 65: 2465-2473, 2005.

61. Melillo RM, Castellone MD, Guarino V, De Falco V, Cirafici AM Salvatore G, Caiazzo F, Basolo F, Giannini R, Kruhoffer M, et al The RET/PTC-RAS-BRAF linear signaling cascade mediates the motile and mitogenic phenotype of thyroid cancer cells. J Clin Invest 115: 1068-1081, 2005.

62. Giordano TJ, Kuick R, Thomas DG, Misek DE, Vinco M, Sanders D, Zhu Z, Ciampi R, Roh M, Shedden K, et al: Molecular classification of papillary thyroid carcinoma: distinct BRAF, RAS, and RET/PTC mutation-specific gene expression profiles discovered by DNA microarray analysis. Oncogene 24: 6646$6656,2005$.

63. Hoque MO, Rosenbaum E, Westra WH, Xing M, Ladenson P, Zeiger MA, Sidransky D and Umbricht CB: Quantitative assessment of promoter methylation profiles in thyroid neoplasms. J Clin Endocrinol Metab 90: 4011-4018, 2005.

64. Hu S, Liu DX, Tufano RP, Carson KA, Rosenbaum E, Cohen Y, Holt EH, Kiseljak-Vassiliades K, Rhoden KJ, Tolaney S, et al: Association of aberrant methylation of tumor suppressor genes with tumor aggressiveness and BRAF mutation in papillary thyroid cancer. Int J Cancer 119: 2322-2329, 2006.

65. Hou P, Liu D and Xing M: Genome-wide alterations in gene methylation by the BRAF V600E mutation in papillary thyroid cancer cells. Endocr Relat Cancer 18: 687-697, 2011.

66. Porra V, Ferraro-Peyret C, Durand C, Selmi-Ruby S, Giroud H, Berger-Dutrieux N, Decaussin M, Peix JL, Bournaud C, Orgiazzi J, et al: Silencing of the tumor suppressor gene SLC5A8 is associated with BRAF mutations in classical papillary thyroid carcinomas. J Clin Endocrinol Metab 90: 3028-3035, 2005.

67. Anand-Apte B, Bao L, Smith R, Iwata K, Olsen BR, Zetter B and Apte SS: A review of tissue inhibitor of metalloproteinases-3 (TIMP-3) and experimental analysis of its effect on primary tumor growth. Biochem Cell Biol 74: 853-862, 1996

68. Qi JH, Ebrahem Q, Moore N, Murphy G, Claesson-Welsh L, Bond M, Baker A and Anand-Apte B: A novel function for tissue inhibitor of metalloproteinases-3 (TIMP3): inhibition of angiogenesis by blockage of VEGF binding to VEGF receptor-2. Nat Med 9: 407-415, 2003.

69. Chou CK, Chen RF, Chou FF, Chang HW, Chen YJ, Lee YF, Yang KD, Cheng JT, Huang CC and Liu RT: miR-146b is highly expressed in adult papillary thyroid carcinomas with high risk features including extrathyroidal invasion and the BRAF(V600E) mutation. Thyroid 20: 489-494, 2010.
70. Cahill S, Smyth P, Denning K, Flavin R, Li J, Potratz A, Guenther SM, Henfrey R, O'Leary JJ and Sheils O: Effect of BRAFV600E mutation on transcription and post-transcriptional regulation in a papillary thyroid carcinoma model. Mol Cancer 6: $21,2007$.

71. Yoon H, He H, Nagy R, Davuluri R, Suster S, Schoenberg D, Pellegata $\mathrm{N}$ and Chapelle AL: Identification of a novel noncoding RNA gene, NAMA, that is downregulated in papillary thyroid carcinoma with BRAF mutation and associated with growth arrest. Int J Cancer 121: 767-775, 2007.

72. Palona I, Namba H, Mitsutake N, Starenki D, Podtcheko A, Sedliarou I, Ohtsuru A, Saenko V, Nagayama Y, Umezawa K and Yamashita S: BRAFV600E promotes invasiveness of thyroid cancer cells through nuclear factor $\mathrm{kB}$ activation. Endocrinology 147: 5699-5707, 2006.

73. Karin M: Nuclear factor-kB in cancer development and progression. Nature 441: 431-436, 2006.

74. Deryugina EI and Quigley JP: Matrix metalloproteinases and tumor metastasis. Cancer Metastasis Rev 25: 9-34, 2006.

75. Jo YS, Li S, Song JH, Kwon KH, Lee JC, Rha SY, Lee HJ, Sul JY, Kweon GR, Ro HK, Kim JM and Shong M: Influence of the BRAF V600E mutation on expression of vascular endothelial growth factor in papillary thyroid cancer. J Clin Endocrinol Metab 91: 3667-3670, 2006

76. Grabellus F, Worm K, Schmid KW and Sheu-Grabellus SY: The BRAF V600E mutation in papillary thyroid carcinomas is associated with glucose transporter 1 (GLUT1) overexpression. Thyroid 22: 377-382, 2012.

77. Nilsson M: Iodide handling by the thyroid epithelial cell. Exp Clin Endocrinol Diabetes 109: 13-17, 2001.

78. Arturi F, Russo D, Bidart JM, Scarpelli D, Schlumberger M and Filetti S: Expression pattern of the pendrin and sodium/iodide symporter genes in human thyroid carcinoma cell lines and human thyroid tumors. Eur J Endocrinol 145: 129-135, 2001.

79. Ringel MD, Anderson J, Souza SL, Burch HB, Tambascia M, Shriver CD and Tuttle RM: Expression of the sodium iodide symporter and thyroglobulin genes are reduced in papillary thyroid cancer. Mod Pathol 14: 289-296, 2001.

80. Durante C, Puxeddu E, Ferretti E, Morisi R, Moretti S, Bruno R, Barbi F, Avenia N, Scipioni A, Verrienti A, et al: BRAF mutations in papillary thyroid carcinomas inhibit genes involved in iodine metabolism. J Clin Endocrinol Metab 92: 2840-2843, 2007.

81. Mian C, Barollo S, Pennelli G, Pavan N, Rugge M, Pelizzo MR, Mazzarotto R, Casara D, Nacamulli D, Mantero F, et al: Molecular characteristics in papillary thyroid cancers (PTCs) with no (131)I uptake. Clin Endocrinol 68: 108-116, 2008.

82. Di Cristofaro J, Silvy M, Lanteaume A, Marcy M, Carayon P and De Micco C: Expression of tpo mRNA in thyroid tumors: quantitative PCR analysis and correlation with alterations of ret, Braf, ras and pax8 genes. Endocr Relat Cancer 13: 485-495, 2006.

83. Riesco-Eizaguirre G, Gutierrez-Martinez P, Garcia-Cabezas MA, Nistal M and Santisteban P: The oncogene BRAF V600E is associated with a high risk of recurrence and less differentiated papillary thyroid carcinoma due to the impairment of $\mathrm{Na}^{+} / \mathrm{I}$ targeting to the membrane. Endocr Relat Cancer 13: 257-269, 2006.

84. Liu D, Hu S, Hou P, Jiang D, Condouris S and Xing M: Suppression of $\mathrm{BRAF} / \mathrm{MEK} / \mathrm{MAP}$ kinase pathway restores expression of iodide-metabolizing genes in thyroid cells expressing the V600E BRAF mutant. Clin Cancer Res 13: 1341-1349, 2007.

85. Ikuyama S, Niller HH, Shimura H, Akamizu T and Kohn LD: Characterization of the 5-flanking region of the rat thyrotropin receptor gene. Mol Endocrinol 6: 793-804, 1992.

86. Yokomori N, Tawata M, Saito T, Shimura H and Onaya T: Regulation of the rat thyrotropin receptor gene by the methylationsensitive transcription factor GA-binding protein. Mol Endocrinol 12: 1241-1249, 1998.

87. Xing M, Usadel H, Cohen Y, Tokumaru Y, Guo Z, Westra WB, Tong BC, Tallini G, Udelsman R, Califano JA, Ladenson PW and Sidransky D: Methylation of the thyroid-stimulating hormone receptor gene in epithelial thyroid tumors: a marker of malignancy and a cause of gene silencing. Cancer Res 63: 2316-2321, 2003

88. Schagdarsurengin U, Gimm O, Dralle H, Hoang-Vu C and Dammann R: CpG island methylation of tumor-related promoters occurs preferentially in undifferentiated carcinoma. Thyroid 16: 633-642, 2006.

89. Xing M: BRAF mutation in papillary thyroid cancer: pathogenic role, molecular bases, and clinical implications. Endocr Rev 28: 742-762, 2007. 
90. Abrosimov A, Saenko V, Rogounovitch T, Namba H, Lushnikov E, Mitsutake N and Yamashita S: Different structural components of conventional papillary thyroid carcinoma display mostly identical BRAF status. Int J Cancer 120: 196-200, 2007.

91. Adeniran AJ, Zhu Z, Gandhi M, Steward DL, Fidler JP, Giordano TJ, Biddinger PW and Nikiforov YE: Correlation between genetic alterations and microscopic features, clinical manifestations, and prognostic characteristics of thyroid papillary carcinomas. Am J Surg Pathol 30: 216-222, 2006.

92. Fugazzola L, Mannavola D, Cirello V, Vannucchi G, Muzza M, Vicentini L and Beck-Peccoz P: BRAF mutations in an Italian cohort of thyroid cancers. Clin Endocrinol 61: 239-243, 2004.

93. Fugazzola L, Puxeddu E, Avenia N, Romei C, Cirello V, Cavaliere A, Faviana P, Mannavola D, Moretti S, Rossi S, et al: Correlation between B-RAFV600E mutation and clinicopathologic parameters in papillary thyroid carcinoma: data from a multicentric Italian study and review of the literature. Endocr Relat Cancer 13: 455-464, 2006.

94. Jin L, Sebo TJ, Nakamura N, Qian X, Oliveira A, Majerus JA, Johnson MR and Lloyd RV: BRAF mutation analysis in fine needle aspiration (FNA) cytology of the thyroid. Diagn Mol Pathol 15: 136-143, 2006.

95. Kebebew E, Weng J, Bauer J, Ranvier G, Clark OH, Duh QY, Shibru D, Bastian B and Griffin A: The prevalence and prognostic value of BRAF mutation in thyroid cancer. Ann Surg 246 : 466-471, 2007

96. Kim KH, Kang DW, Kim SH, Seong IO and Kang DY: Mutations of the BRAF gene in papillary thyroid carcinoma in a Korean population. Yonsei Med J 45: 818-821, 2004.

97. Kim KH, Suh KS, Kang DW and Kang DY: Mutations of the BRAF gene in papillary thyroid carcinoma and in Hashimoto's thyroiditis. Pathol Int 55: 540-545, 2005.

98. Kim TY, Kim WB, Song JY, Rhee YS, Gong G, Cho YM, Kim SY, Kim SC, Hong SJ and Shong YK: The BRAF mutation is not associated with poor prognostic factors in Korean patients with conventional papillary thyroid microcarcinoma. Clin Endocrinol (Oxf) 63: 588-593, 2005.

99. Kim TY, Kim WB, Rhee YS, Song JY, Kim JM, Gong G, Lee S, Kim SY, Kim SC, Hong SJ and Shong YK: The BRAF mutation is useful for prediction of clinical recurrence in low-risk patients with conventional papillary thyroid carcinoma. Clin Endocrinol (Oxf) 65: 364-368, 2006

100.Kim J, Giuliano AE, Turner RR, Gaffney RE, Umetani N, Kitago M, Elashoff D and Hoon DS: Lymphatic mapping establishes the role of BRAF gene mutation in papillary thyroid carcinoma. Ann Surg 244: 799-804, 2006.

101.Liu RT, Chen YJ, Chou FF, Li CL, Wu WL, Tsai PC, Huang CC and Cheng JT: No correlation between BRAFV600E mutation and clinicopathological features of papillary thyroid carcinomas in Taiwan. Clin Endocrinol (Oxf) 63: 461-466, 2005

102.Lupi C, Giannini R, Ugolini C, Proietti A, Berti P, Minuto M Materazzi G, Elisei R, Santoro M, Miccoli P and Basolo F: Association of BRAF V600E mutation with poor clinicopathologic outcomes in 500 consecutive cases of papillary thyroid carcinoma. J Clin Endocrinol Metab 92: 4085-4090, 2007.

103.Lee JH, Lee ES, Kim YS, Won NH and Chae YS: BRAF mutation and AKAP9 expression in sporadic papillary thyroid carcinomas. Pathology 38: 201-204, 2006.

104. Mitsiades CS, Negri J, McMullan C, McMillin DW, Sozopoulos E, Fanourakis G, Voutsinas G, Tseleni-Balafouta S, Poulaki V, Batt D and Mitsiades N: Targeting BRAFV600E in thyroid carcinoma: therapeutic implications. Mol Cancer Ther 6: 1070-1078, 2007

105. Nikiforova MN, Kimura ET, Gandhi M, Biddinger PW, Knauf JA, Basolo F, Zhu Z, Giannini R, Salvatore G, Fusco A, et al: BRAF mutations in thyroid tumors are restricted to papillary carcinomas and anaplastic or poorly differentiated carcinomas arising from papillary carcinomas. J Clin Endocrinol Metab 88 5399-5404, 2003.

106. Park SY, Park YJ, Lee YJ, Lee HS, Choi SH, Choe G, Jang HC, Park SH, Park do J and Cho BY: Analysis of differential BRAF (V600E) mutational status in multifocal papillary thyroid carcinoma: evidence of independent clonal origin in distinct tumor foci. Cancer 107: 1831-1838, 2006.

107. Rodolico V, Cabibi D, Pizzolanti G, Richiusa P, Gebbia N, Martorana A, Russo A, Amato MC, Galluzzo A and Giordano C: BRAF(V600E) mutation and $\mathrm{p} 27$ (kip1) expression in papillary carcinomas of the thyroid $\leq 1 \mathrm{~cm}$ and their paired lymph node metastases. Cancer 110: 1218-1226, 2007.
108. Sedliarou I, Saenko V, Lantsov D, Rogounovitch T, Namba H, Abrosimov A, Lushnikov E, Kumagai A, Nakashima M, Meirmanov S, et al: The BRAFT1796A transversion is a prevalent mutational event in human thyroid microcarcinoma. Int J Oncol 25: 1729-1735, 2004

109. Trovisco V, Soares P, Preto A, de Castro IV, Lima J, Castro P, Maximo V, Botelho T, Moreira S, Meireles AM, et al: Type and prevalence of BRAF mutations are closely associated with papillary thyroid carcinoma histotype and patients' age but not with tumour aggressiveness. Virchows Arch 446: 589-595, 2005.

110. Xing M, Westra WH, Tufano RP, et al: BRAF mutation predicts a poorer clinical prognosis for papillary thyroid cancer. J Clin Endocrinol Metab 90: 6373-6379, 2005.

111. Powell N, Jeremiah S, Morishita M, Dudley E, Bethel J, Bogdanova T, Tronko M and Thomas G: Frequency of BRAF T1796A mutation in papillary thyroid carcinoma relates to age of patient at diagnosis and not to radiation exposure. J Pathol 205: 558-564, 2005

112. Sapio MR, Posca D, Troncone G, Pettinato G, Palombini L, Rossi G, Fenzi G and Vitale M: Detection of BRAF mutation in thyroid papillary carcinomas by mutant allele-specific PCR amplification (MASA). Eur J Endocrinol 154: 341-348, 2006.

113. Frasca F, Nucera C, Pellegriti G, Gangemi P, Attard M, Stella M, Loda M, Vella V, Giordano C, Trimarchi F, et al: BRAF(V600E) mutation and the biology of papillary thyroid cancer. Endocr Relat Cancer 15: 191-205, 2008.

114. Cañadas Garre M, López de la Torre Casares M, Becerra Massare P, López Nevot MÁ, Villar Del Moral J, Muñoz Pérez N, Vílchez Joya R, Montes Ramírez R and Llamas Elvira JM: BRAF(T1799A) mutation in the primary tumor as a marker of risk, recurrence, or persistence of papillary thyroid carcinoma. Endocrinol Nutr 58: 175-184, 2011.

115. Chakraborty A, Narkar A, Mukhopadhyaya R, Kane S, D'Cruz A and Rajan MG: BRAF (V600E) Mutation in papillary phyroid carcinoma: significant association with node metastases and extra thyroidal invasion. Endocr Pathol 23:83-93, 2012.

116. Nam JK, Jung CK, Song BJ, Lim DJ, Chae BJ, Lee NS, Park WC, Kim JS, Jung SS and Bae JS: Is the BRAF(V600E) mutation useful as a predictor of preoperative risk in papillary thyroid cancer? Am J Surg 203: 436-441, 2011.

117. Kim SJ, Lee KE, Myong JP, Park JH, Jeon YK, Min HS, Park SY, Jung KC, Koo do H and Youn YK: BRAF(V600E) mutation is associated with tumor aggressiveness in papillary thyroid cancer. Word J Surg 36: 310-317, 2012

118. Begum S, Rosenbaum E, Henrique R, Cohen Y, Sidransky D and Westra WH: BRAF mutations in anaplastic thyroid carcinoma: implications for tumor origin, diagnosis and treatment. Mod Pathol 17: 1359-1363, 2004.

119. Quiros RM, Ding HG, Gattuso P, Prinz RA and Xu X: Evidence that one subset of anaplastic thyroid carcinomas are derived from papillary carcinomas due to BRAF and p53 mutations. Cancer 103: 2261-2268, 2005.

120. Takano T, Ito Y, Hirokawa M, Yoshida H and Miyauchi A: BRAF V600E mutation in anaplastic thyroid carcinomas and their accompanying differentiated carcinomas. Br J Cancer 96: 1549-1553, 2007.

121. Ito $\mathrm{Y}$, Yoshida $\mathrm{H}$, Maruo R, et al: BRAF mutation in papillary thyroid carcinoma in a Japanese population: its lack of correlation with high-risk clinicopathologic features and disease-free survival of patients. Endocrine J 56: 89-97, 2009.

122. Howell GM, Carty SE, Armstrong MJ, Lebeau SO, Hodak SP, Coyne C, Stang MT, McCoy KL, Nikiforova MN, Nikiforov YE and Yip L: Both BRAF V600E mutation and older age $(\geq 65$ years) are associated with recurrent papillary thyroid cancer. Ann Surg Oncol 18: 3566-3571, 2011

123. Ain KB: Management of undifferentiated thyroid cancer. Baillieres Best Pract Res Clin Endocrinol Metab 14: 615-629, 2000

124. Chung KW, Yang SK, Lee GK, Kim EY, Kwon S, Lee SH, Park do J, Lee HS, Cho BY, Lee ES and Kim SW: Detection of BRAFV600E mutation on fine needle aspiration specimens of thyroid nodule refines cyto-pathology diagnosis, especially in BRAF600E mutation-prevalent area. Clin Endocrinol (Oxf) 65: 660-666, 2006.

125. Patel A, Klubo-Gwiezdzinska J, Hoperia V, Larin A, Jensen K, Bauer A and Vasko V: BRAF(V600E) mutation analysis from May-Grünwald Giemsa-stained cytological samples as an adjunct in identification of high-risk papillary thyroid carcinoma. Endocr Pathol 22: 195-199, 2011. 
126. Rowe LR, Bentz BG and Bentz JS: Utility of BRAF V600E mutation detection in cytologically indeterminate thyroid nodules. Cytojournal 3: 10, 2006.

127. Marchetti I, Lessi F, Mazzanti CM, Bertacca G, Elisei R, Coscio GD, Pinchera A and Bevilacqua G: A morpho-molecular diagnosis of papillary thyroid carcinoma: BRAF V600E detection as an important tool in preoperative evaluation of fineneedle aspirates. Thyroid 19: 837-842, 2009

128. Colanta A, Lin O, Tafe L, Ghossein R, Nafa K, Mitchell T, Ladanyi M and Arcila M: BRAF mutation analysis of fine-needle aspiration biopsies of papillary thyroid carcinoma: Impact on diagnosis and prognosis. Acta Cytol 55: 563-569, 2011.

129. Bollag G, Hirth P, Tsai J, et al: Clinical efficacy of a RAF inhibitor needs broad target blockade in BRAF-mutant melanoma. Nature 467: 596-569, 2010.

130. Nucera C, Porrello A, Antonello ZA, Mekel M, Nehs MA, Giordano TJ, Gerald D, Benjamin LE, Priolo C, Puxeddu E, et al: B-Raf(V600E) and thrombospondin-1 promote thyroid cancer progression Proc Natl Acad Sci USA 107: 10649-10654, 2010.

131. Nucera C, Nehs MA, Mekel M, Zhang X, Hodin R, Lawler J, Nose V and Parangi S: A novel orthotopic mouse model of human anaplastic thyroid carcinoma. Thyroid 19: 1077-1084, 2009.
132. Liu D, Liu Z, Jiang D, Dackiw AP and Xing M: Inhibitory effects of the mitogen-activated protein kinase kinase inhibitor CI-1040 on the proliferation and tumor growth of thyroid cancer cells with BRAF or RAS mutations. J Clin Endocrinol Metab 92: 4686-4695, 2007.

133. Henderson YC, Fredrick MJ and Clayman GL: Differential responses of human papillary thyroid cancer cell lines carrying the RET/PTC1 rearrangement or a BRAF mutation to MEK1/2 inhibitors. Arch Otolaryngol Head Neck Surg 133: 810-815, 2007.

134. Wallace EM, Lyssikatos JP, Yeh T, Winkler JD and Koch K: Progress towards therapeutic small molecule MEK inhibitors for use in cancer therapy. Curr Top Med Chem 5: 215-229, 2005.

135. Wang D, Boerner SA, Winkler JD, and LoRusso PM: Clinical experience of MEK inhibitors in cancer therapy. Biochim Biophys Acta 1773: 1248-1255, 2007. 